Accepted for publication in Paleoceanography (http://dx.doi.org/10.1002/2016PA002978)

\title{
Biogeochemical cycling in the Bering Sea over the onset of major Northern Hemisphere Glaciation
}

\section{George E. A. Swann'1, Andrea M. Snelling ${ }^{1,2}$, Jennifer Pike ${ }^{3}$}

${ }^{1}$ School of Geography, Centre for Environmental Geochemistry, University of Nottingham, University Park, Nottingham, NG7 2RD, UK.

${ }^{2}$ NERC Isotope Geosciences Facilities, British Geological Survey, Nottingham, NG12 5GG, UK.

${ }^{3}$ School of Earth and Ocean Sciences, Cardiff University, Main Building, Park Place, Cardiff, CF10 3AT, UK.

Corresponding author: George Swann (george.swann@nottingham.ac.uk)

\section{Key Points:}

- Nutrient leakage from the subarctic North Pacific Ocean to Bering Sea from 2.73 Ma

- Abrupt increase in silicic acid supply at 2.58 Ma increases siliceous productivity in the Bering Sea

- Bering Sea productivity increase at $2.58 \mathrm{Ma}$ are concordant with shift to permanently colder conditions 
Accepted for publication in Paleoceanography (http://dx.doi.org/10.1002/2016PA002978)

\section{Abstract}

The Bering Sea is one of the most biologically productive regions in the marine system and plays a key role in regulating the flow of waters to the Arctic Ocean and into the subarctic North Pacific Ocean. Cores from IODP Expedition 323 to the Bering Sea provide the first opportunity to obtain reconstructions from the region that extend back to the Pliocene. Previous research at Bowers Ridge, south Bering Sea, has revealed stable levels of siliceous productivity over the onset of major Northern Hemisphere Glaciation (NHG) (c. 2.85-2.73 Ma). However, diatom silica isotope records of oxygen $\left(\delta^{18} \mathrm{O}_{\text {diatom }}\right)$ and silicon $\left(\delta^{30} \mathrm{Si}_{\text {diatom }}\right)$ presented here demonstrate that this interval was associated with a progressive increase in the supply of silicic acid to the region, superimposed on shift to a more dynamic environment characterized by colder temperatures and increased sea ice. This concluded at $2.58 \mathrm{Ma}$ with a sharp increase in diatom productivity, further increases in photic zone nutrient availability and a permanent shift to colder sea surface conditions. These transitions are suggested to reflect a gradually more intense nutrient leakage from the subarctic northwest Pacific Ocean, with increases in productivity further aided by increased sea-ice and wind-driven mixing in the Bering Sea. In suggesting a linkage in biogeochemical cycling between the south Bering Sea and subarctic Northwest Pacific Ocean, mainly via the Kamchatka Strait, this work highlights the need to consider the interconnectivity of these two systems when future reconstructions are carried out in the region.

\section{Introduction}

The progressive advancement of ice sheets across the Northern Hemisphere in the late Pliocene and the development of glacial-interglacial cycles which punctuate the Quaternary mark a significant threshold in Earth's climate history [Ravelo et al., 2004]. Of particular note are the transitions associated with the onset of major Northern Hemisphere Glaciation (NHG), c. 2.852.73 Ma, when large ice sheets developed across Greenland, Eurasia and Northern America [Raymo 1994; Maslin et al., 1996; Hidy et al., 2013]. Investigating the changes that occurred over this time-frame is important for understanding the long-term functionality and temporal variability of the global climate system [Mudelsee and Raymo, 2005]. Until recently the paucity of cores from the Bering Sea prevented a reconstruction of regional oceanographic conditions beyond the last glacial cycle. The absence of such records is notable given the sea is one of the most highly productive high-nutrient low-chlorophyll (HNLC) marine systems [Sambrotto et al., 1984; Brown et al., 2011]. For the first time, cores from IODP Expedition 323 allow the history of the Bering Sea to be reconstructed over the Pliocene/Quaternary interval with Site U1341, situated on the western flank of Bowers Ridge south of the modern sea ice extent (Fig. 1), permitting an examination of how conditions are interlinked with the wider North Pacific region [Takahashi et al., 2011; Kinney and Maslowski, 2012].

Prior to IODP Expedition 323, knowledge of the long-term behavior of the wider subarctic region was primarily restricted to reconstructions from ODP Site 882 in the subarctic Northwest Pacific Ocean which show a major restructuring of oceanographic conditions over the onset of NHG (Fig. 1). Throughout the mid-Pliocene records from ODP Site 882 indicate a mixed water column characterized by high opal mass accumulation rates (MAR) (c. $3 \mathrm{~g} \mathrm{~cm}^{-2} \mathrm{ka}^{-}$ ${ }^{1}$ ), conditions that would have helped maintain a warm climate state via significant deep water upwelling and ventilation of $\mathrm{CO}_{2}$ to the atmosphere [Haug et al., 1999; Haug et al., 2005]. After $2.73 \mathrm{Ma}$ increases in surface freshwater led to the formation of a halocline that initiated a collapse in siliceous productivity (opal MAR $=<1 \mathrm{~g} \mathrm{~cm}^{-2} \mathrm{ka}^{-1}$ ), altered biogeochemical cycling 
Accepted for publication in Paleoceanography (http://dx.doi.org/10.1002/2016PA002978)

and increased transportation of water vapor to North America [Haug et al., 1999; Sigman et al., 2004; Haug et al., 2005; Swann et al., 2006; Reynolds et al., 2008; Shimada et al., 2009; Swann 2010; Bailey et al., 2011; Studer et al., 2012].

In contrast to ODP Site 882, records at Site U1341 in the Bering Sea remain stable and show no collapse in siliceous productivity at $2.73 \mathrm{Ma}$ and over the onset of NHG [Iwasaki et al., 2016]. Instead, fluxes of both biogenic opal (from c. $2-4 \mathrm{~g} \mathrm{~cm}^{-2} \mathrm{ka}^{-1}$ to c. $8-12 \mathrm{~g} \mathrm{~cm}^{-2} \mathrm{ka}^{-1}$ ) and organic carbon (from $<0.1 \mathrm{~mol} \mathrm{C} \mathrm{m}^{-2} \mathrm{y}^{-1}$ to c. $0.3 \mathrm{~mol} \mathrm{C} \mathrm{m}^{-2} \mathrm{y}^{-1}$ ) increase abruptly later at 2.58 Ma [März et al., 2013; Wehrmann et al., 2013; Iwasaki et al., 2016]. Two alternative explanations exist that link the increase in siliceous productivity at Site U1341 from 2.58 Ma to oceanographic changes in the subarctic North Pacific Ocean. Stratification and associated reductions in productivity and nutrient utilization at ODP Site 882 [Haug et al., 1999; Sigman et al., 2004; Reynolds et al., 2008; Bailey et al., 2011] could have led to the export of nutrient-rich deep/intermediate waters that were upwelled at Bowers Ridge to fuel the productivity increase at Site U1341 [März et al., 2013]. This mechanism is consistent with evidence for a global change in patterns of opal sedimentation, nutrient availability and the efficiency of the biological pump at the Pliocene/Quaternary boundary [Cortese et al., 2004; Etourneau et al., 2012], but does not account for the time lag between the establishment of the halocline at ODP Site 882 (2.73 Ma) and the increase in opal at U1341 (2.58 Ma). An alternative hypothesis, building on the status of the Bering Sea as a HNLC region, links the high opal MAR from 2.58 Ma to iron fertilization from the Bering Sea continental shelf [Iwasaki et al., 2016].

Diatom silicon isotope $\left(\delta^{30} \mathrm{Si}_{\text {diatom }}\right)$ measurements are presented from Site U1341, between 2.93-2.52 Ma, in order to better constrain changes in biogeochemical cycling in the south Bering Sea and to obtain insights into how the region responded to the abrupt reorganization of the subarctic northwest Pacific Ocean at 2.73 Ma. Silicon, in the form of silicic acid $\left[\mathrm{Si}(\mathrm{OH})_{4}\right]$ is a key nutrient for diatoms. During the biomineralisation of silicic acid into particulate hydrous silica the lighter ${ }^{28} \mathrm{Si}$ isotope is preferentially taken up by diatoms over the heavier stable isotopes ${ }^{29} \mathrm{Si}$ and ${ }^{30} \mathrm{Si}$, with an enrichment factor $(\varepsilon)$ of $-1.1 \%$ o to $-1.2 \%$ o that is independent of temperature, $p \mathrm{CO} 2_{(\mathrm{aq})}$, iron availability and other vital effects [De La Rocha et al., 1997; Milligan et al., 2004; Varela et al., 2004; Fripiat et al., 2011]. With progressive uptake of $\mathrm{Si}(\mathrm{OH})_{4}$ increasing the $\delta^{30} \mathrm{Si}\left({ }^{30} \mathrm{Si} /{ }^{28} \mathrm{Si}\right)$ of $\mathrm{Si}(\mathrm{OH})_{4}$ remaining in the water column via Rayleigh distillation, values of $\delta^{30} \mathrm{Si}_{\text {diatom }}$ reflect changes in the rate of silicic acid $\left[\mathrm{Si}(\mathrm{OH})_{4}\right]$ utilization and/or supply of $\mathrm{Si}(\mathrm{OH})_{4}$ to the photic zone [De La Rocha, 2006; Hendry and Brzezinski, 2014]. Accordingly, records of $\delta^{30} \mathrm{Si}_{\text {diatom }}$ can be used to constrain the alternative mechanisms that initiated the opal increase at U1341 from 2.58 Ma onwards. A nutrient leakage from the subarctic North Pacific Ocean would be expected to increase the supply of $\mathrm{Si}(\mathrm{OH})_{4}$ to the photic zone at Site U1341. Changes in $\mathrm{Si}(\mathrm{OH})_{4}$ utilization may also occur under this scenario, depending on the net efficiency of the biological pump. In contrast, iron fertilization should only lead to a change in rate of $\mathrm{Si}(\mathrm{OH})_{4}$ utilization at Site U1341, due to the resultant reduction in diatom frustule Si:N uptake ratios [Hutchins and Bruland, 1998; Takeda, 1998]. Diatom silica oxygen isotope measurements $\left(\delta^{18} \mathrm{O}_{\text {diatom }}\right)$ reflect surface water temperature and salinity conditions [Swann and Leng, 2009] and are also presented between 2.93-2.52 Ma in order to provide information on the wider surface ocean environment. 
Accepted for publication in Paleoceanography (http://dx.doi.org/10.1002/2016PA002978)

\section{Methods}

\subsection{Age models}

The age model for Site U1341 is taken from Iwasaki et al. [2016] in which linear sedimentation rates are applied between 13 age control point based on shipboard paleomagnetic measurements and refined biostratigraphy [Expedition 323 Scientists, 2011; Takahashi et al., 2011; Onodera et al., 2016; Ikenoue et al., 2016]. The sedimentation rates, age controls points and respective errors for the interval analyzed in this study [reported in Table 1 of Iwasaki et al., 2016] are shown in Figure 2. Whilst the ages of some control points are well established (e.g., top of Gauss at $2.581 \mathrm{Ma}$ ) the biostratigraphic datums have uncertainties of up to $0.08 \mathrm{Ma}$. To address this overlap of datum events within their uncertainties, the average depths of datum events were used to establish ages at 2.48 and 2.65 Ma [see full details in Iwasaki et al., 2016]. The impact of age model uncertainties on the linear sedimentation rates and the increase in opal MAR at 2.6 Ma are fully discussed in Iwasaki et al. [2016]. Whilst Iwasaki et al. [2016] acknowledge that uncertainties in the age model may impact the absolute opal MAR values, they remain confident that the increase in opal MAR represents a marked increase in biological productivity rather than an age-model artefact.

\subsection{Diatom isotopes}

Seventy samples from Site U1341B $\left(54^{\circ} 1.9984^{\prime} \mathrm{N}, 179^{\circ} 0.5171^{\prime} \mathrm{E}\right.$; water depth $\left.=2,140 \mathrm{~m}\right)$ on Bowers Ridge in the south Bering Sea, dated between 2.93-2.52 Ma, were prepared for diatom isotope analysis using a combination of heavy liquid separation and reagents to remove contaminants [Swann et al., 2013]. Samples were sieved at $38 \mu \mathrm{m}, 15 \mu \mathrm{m}$ and at $3 \mu \mathrm{m}$ using a sieve cloth to isolate diatoms from sponge spicules that reflect bottom water conditions and possess different fractionation factors to diatoms [de la Rocha, 2003; Wille et al., 2010; Hendry and Robinson, 2012; Snelling et al., 2014]. Sample size fractions were screened using a Zeiss Axiovert $40 \mathrm{C}$ inverted microscope, scanning electron microscope (SEM) and X-ray fluorescence (XRF) to confirm sample purity and the absence of non-diatom contaminants; the cleanest size fraction was retained for isotope analysis. Out of the seventy samples, 68 were analyzed for $\delta^{18} \mathrm{O}_{\text {diatom }}$ and 24 for $\delta^{30} \mathrm{Si}_{\text {diatom. }}$ Of the 68 samples analyzed for $\delta^{18} \mathrm{O}_{\text {diatom, }} 26$ were from the $>38 \mu \mathrm{m}$ fraction and 42 from the 3-15 $\mu \mathrm{m}$ fraction. Previous research found a significant offset between different diatom size fractions analyzed for $\delta^{18} \mathrm{O}_{\text {diatom }}$ [Swann et al., 2007, 2008]. However, comparison of 18 pairs of 3-15 $\mu \mathrm{m}$ and $>38 \mu \mathrm{m}$ size fraction samples at Site U1341, selected from throughout the analyzed interval, reveals no offset beyond analytical reproducibility. Diatoms in the $>38 \mu \mathrm{m}$ size fraction are dominated by Actinocyclus curvatulus, Coscinodiscus marginatus and Shionodiscus trifultus. The 3-15 $\mu \mathrm{m}$ size fraction is composed of a variety of taxa including Neodenticula seminae and Neodenticula koizumii together with fragments from larger taxa. Given the diversity of taxa in the analyzed samples, our isotope records are interpreted as recording mean annual conditions with a significant bias towards spring months when productivity peaks [Rho and Whitledge, 2007; Brown et al., 2011; Sigler et al., 2014].

Samples were analyzed for $\delta^{18} \mathrm{O}_{\text {diatom }}$ and $\delta^{30} \mathrm{Si}_{\text {diatom }}$ using a combined step-wise fluorination procedure at the NERC Isotope Geosciences Facility based at the British Geological Survey [Leng and Sloane, 2008]. $\delta^{18} \mathrm{O}_{\text {diatom }}$ and $\delta^{30} \mathrm{Si}_{\text {diatom }}$ were measured on a Finnigan MAT 253 with results converted to the Vienna Standard Mean Ocean Water (VSMOW) and NBS28 
Accepted for publication in Paleoceanography (http://dx.doi.org/10.1002/2016PA002978)

scale, respectively, using the within-run laboratory diatom standard $\mathrm{BFC}_{\text {mod }}$ which has been calibrated against NBS28. These methods have been verified through inter-laboratory calibration exercises for both $\delta^{18} \mathrm{O}_{\text {diatom }}$ [Chapligin et al., 2011] and $\delta^{30} \mathrm{Si}_{\text {diatom [Reynolds et al., 2007]. }}$ Replicate analyses of sample material across the interval analyzed from Site U1341 indicate an analytical reproducibility $(1 \sigma)$ of $0.4 \%$ and $0.09 \%$ for $\delta^{18} \mathrm{O}_{\text {diatom }}$ and $\delta^{30} \mathrm{Si}_{\text {diatom }}$, respectively.

\subsection{Silicic acid utilization/supply}

The isotope fractionation of silicon during biological uptake can be considered within the context of either a closed or open system model under Rayleigh fractionation. In a closed system model all $\mathrm{Si}(\mathrm{OH})_{4}$ is supplied to the photic zone prior to biological uptake. In open ocean systems, such as the region around Site U1341, silicon dynamics are best represented by an open system model marked by continuous supply of silicic acid to the photic zone. In this, through Rayleigh distillation, changes in $\delta^{30} \mathrm{Si}_{\text {diatom }}$ are a function of the isotopic composition of the dissolved silicic acid $\left[\delta^{30} \mathrm{Si}(\mathrm{OH})_{4}\right]$ supplied to the photic zone, the fraction of $\mathrm{Si}(\mathrm{OH})_{4}$ remaining in the water (f) and the enrichment factor between diatoms and dissolved silicic acid $(\varepsilon)$ :

$$
\delta^{30} \mathrm{Si}_{\text {diatom }}=\delta^{30} \mathrm{Si}(\mathrm{OH})_{4}+\varepsilon * \mathrm{f}
$$

No investigation into the contemporary $\delta^{30} \mathrm{Si}$ systematics of the Bering Sea has been undertaken. Research in the subarctic North Pacific Ocean has measured $\delta^{30} \mathrm{Si}(\mathrm{OH})_{4}$ at $1.23 \pm$ $0.17 \%$ o $\left(2 \sigma\right.$; water depth $=10 \mathrm{~m}$ at "Station 3": $50^{\circ} 00$ ' N, $\left.167^{\circ} 00^{\prime} \mathrm{E}\right)$ and $\varepsilon$ as -1.0 [Reynolds et al., 2006] and we use these values for the Bering Sea. Using these modern values and extrapolating to the Pliocene/early Quaternary introduces a degree of uncertainty into the quantitative estimates of $\mathrm{Si}(\mathrm{OH})_{4}$ utilization/supply calculated from Equations 2 and 3 below. However, the use of subarctic North Pacific Ocean end-members from a site close to ODP Site 882 is appropriate when testing whether nutrient leakage from the region caused the increase in opal MAR at Site U1341 at 2.58 Ma. Using the modern values, Equation 1 can be re-written to calculate changes in $\mathrm{Si}(\mathrm{OH})_{4}$ utilization $\left[\% \mathrm{Si}(\mathrm{OH})_{4}\right.$ utilization]:

$$
\% \mathrm{Si}(\mathrm{OH})_{4 \text { utilization }}=1-\frac{\delta^{30} \mathrm{Si}_{\text {diatom }}-1.23}{-1.0}
$$

Following Horn et al. (2011) changes in $\mathrm{Si}(\mathrm{OH})_{4}$ utilization between 2.93-2.52 Ma can then be combined with interpolated estimates of opal MAR [Iwasaki et al., 2016] to constrain temporal changes in the relative supply of $\mathrm{Si}(\mathrm{OH})_{4}\left[\% \mathrm{Si}(\mathrm{OH})_{4}\right.$ supply] into the photic zone relative to the youngest sample at $2.52 \mathrm{Ma}$ :

$$
\% \mathrm{Si}(\mathrm{OH})_{4 \text { supply }}=\frac{\mathrm{Opal}_{\text {sample }} / \mathrm{Opal}_{2.52 \mathrm{Ma}}}{\left.\% \mathrm{Si}(\mathrm{OH})_{4 \text { utilization-sample }}\right) /\left(\% \mathrm{Si}(\mathrm{OH})_{4 \text { utilization-2.52 Ma }}\right)}
$$

where $\mathrm{Opal}_{\text {sample }}$ and $\% \mathrm{Si}(\mathrm{OH})_{4}$ utilization-sample are the opal MAR and rate of $\mathrm{Si}(\mathrm{OH})_{4}$ utilization for a given sample respectively and where $\mathrm{Opal}_{2.52 \mathrm{Ma}}$ and $\% \mathrm{Si}(\mathrm{OH})_{4}$ utilization-2.52 Ma are the opal MAR and magnitude of $\mathrm{Si}(\mathrm{OH})_{4}$ utilization in our youngest sample at $2.52 \mathrm{Ma}$. This 
Accepted for publication in Paleoceanography (http://dx.doi.org/10.1002/2016PA002978)

approach assumes that the degree of biogenic silica dissolution through the water column and within the sediment record has remained unchanged over the analyzed interval.

\section{Results}

\section{$3.1 \delta^{30}$ Sidiatom}

$\delta^{30} \mathrm{Si}_{\text {diatom }}$ does not show a large change at Site U1341 over the onset of major NHG (Fig. 2). Between $2.93-2.52 \mathrm{Ma}$ values of $\delta^{30} \mathrm{Si}_{\text {diatom }}$ generally vary between $0.9 \%$ and $1.2 \%$ ( $\overline{\mathrm{x}}=$ $1.0 \%$ o, $1 \sigma= \pm 0.2 \%$ ) with variations in $\delta^{30} \mathrm{Si}_{\text {diatom }}$ from $2.73-2.58 \mathrm{Ma}$ similar to the preceding 200 ka. No clear link exists between changes in $\delta^{30} \mathrm{Si}_{\text {diatom }}$ and glacial/interglacial cycles, although the resolution of the $\delta^{30} \mathrm{Si}_{\text {diatom }}$ record is too low to fully investigate this (Fig. 2). Exceptions to these relatively stable $\delta^{30} \mathrm{Si}_{\text {diatom }}$ values occur in the oldest sample at $2.93 \mathrm{Ma}(0.48 \%)$ and from 2.58 Ma onwards when values range from $0.50 \%$ (2.55 Ma) to $1.36 \%$ (2.53 Ma) (Fig. 2). Estimates of $\mathrm{Si}(\mathrm{OH})_{4}$ utilization follow the patterns in $\delta^{30} \mathrm{Si}_{\text {diatom }}$ and show that the low values of $\delta^{30} \mathrm{Si}_{\text {diatom }}$ at 2.93 Ma and 2.55 Ma are associated with reduced levels of nutrient utilization (Fig. 2). Rates of $\mathrm{Si}(\mathrm{OH})_{4}$ supply to the photic zone were c. $50 \%$, relative to the youngest sample at $2.52 \mathrm{Ma}$, prior to the onset of major NHG at $2.73 \mathrm{Ma}(\overline{\mathrm{x}}=49 \%, 1 \sigma= \pm 8 \%$ ) when excluding the exceptionally high value of $219 \%$ at $2.93 \mathrm{Ma}$ (Fig. 2). After $2.73 \mathrm{Ma}$ rates of supply progressively increased to c. $65 \%$ at $2.60 \mathrm{Ma}(\overline{\mathrm{x}}=59 \%, 1 \sigma= \pm 8 \%$ ). From $2.58 \mathrm{Ma}$ onwards, coinciding with increases in opal MAR [Iwasaki et al., 2016], $\mathrm{Si}(\mathrm{OH})_{4}$ supply to the photic zone abruptly increases to $81-397 \%$ for the remainder of the analyzed interval (Fig. 2) ( $\bar{x}=154 \%$, $1 \sigma$ $=113 \%$ ).

\section{$3.2 \delta^{18} O_{\text {diatom }}$}

Through the late Pliocene $\delta^{18} \mathrm{O}_{\text {diatom }}$ is relatively stable from $2.82-2.93 \mathrm{Ma}(\overline{\mathrm{x}}=39.8 \%$, $1 \sigma= \pm 0.4 \%$ ) (Fig. 2). In the build up to the intensification of NHG (2.73 Ma) and until $2.63 \mathrm{Ma}$ values of $\delta^{18} \mathrm{O}_{\text {diatom }}$ increase and oscillate over a magnitude of 3.0\%o $(\overline{\mathrm{x}}=40.7 \%, 1 \sigma= \pm 0.9 \%$ ). After $2.63 \mathrm{Ma}$ and until $2.58 \mathrm{Ma} \delta^{18} \mathrm{O}_{\text {diatom }}$ becomes more stable, displaying a long term increase to values of c. $42 \%$. After $2.58 \mathrm{Ma}$ until the end of the analyzed interval at $2.52 \mathrm{Ma} \delta^{18} \mathrm{O}_{\text {diatom }}$ remains both high and relatively stable $(\overline{\mathrm{x}}=41.6 \%, 1 \sigma= \pm 0.5 \%$ ) (Fig. 2).

\section{Discussion}

\subsection{Nutrient leakage $v$ iron fertilization}

Two hypotheses exist to explain the opal MAR increase at $2.58 \mathrm{Ma}$ in the south Bering Sea: (1) iron fertilization [Iwasaki et al., 2016]; and (2) nutrient leakage from the North Pacific Ocean [März et al., 2013]. The lack of a concordant change in rates of $\mathrm{Si}(\mathrm{OH})_{4}$ utilization and opal MAR at $2.58 \mathrm{Ma}$ would appear to rule out iron fertilization given that the addition of iron to a HNLC region should alter diatom frustule silicon uptake [Hutchins and Bruland, 1998; Takeda, 1998], although not all studies document a clear relationship between iron fertilization and diatom elemental ratios [e.g., Hoffmann et al., 2007]. The increase in opal MAR and rates of $\mathrm{Si}(\mathrm{OH})_{4}$ supply at $2.58 \mathrm{Ma}$ instead supports the concept of a silicic acid/nutrient leakage fueling the bloom via inflow from the subarctic North Pacific Ocean through the Kamchatka Strait and potentially the Near Strait [März et al., 2013]. Whilst the Kamchatka Strait is a location of significant outflow from the Bering Sea, inflow of $\mathrm{Si}(\mathrm{OH})_{4}$ rich subarctic Pacific waters occurs 
Accepted for publication in Paleoceanography (http://dx.doi.org/10.1002/2016PA002978)

on the eastern side of the strait and at depths [Reed et al., 1993; Cokelet et al., 1996; Coachman et al., 1999; Stabeno et al., 1999] (Fig. 1b).

$\mathrm{Si}(\mathrm{OH})_{4}$ leakage from the subarctic North West Pacific Ocean, linked to the decline in opal MAR and halocline formation at ODP Site 882, would have commenced from 2.73 Ma. However, the opal MAR increase at Site U1341 begins later at $2.58 \mathrm{Ma}$. The $\delta^{30} \mathrm{Si}_{\text {diatom }}$ data from Site U1341 provide an important insight to this time lag by demonstrating that the rate of $\mathrm{Si}(\mathrm{OH})_{4}$ supply to the Bering Sea increased gradually, not abruptly, following the formation of the subarctic North Pacific Ocean halocline at 2.73 Ma through to the opal MAR increase at 2.58 Ma (Fig. 3). Changes in sea level, for which no data exist, could be responsible for this by regulating flow through the Kamchatka Strait and potentially the Near Strait (Fig. 1). Alternatively, the long-term increase in $\mathrm{Si}(\mathrm{OH})_{4}$ supply to Site U1341 may reflect a progressive increase in the intensity of nutrient leakage from the subarctic Pacific over the same interval.

At ODP Site 882, the decrease in opal MAR and development of the halocline leads to anti-correlated records of $\delta^{30} \mathrm{Si}_{\text {diatom }}$ and nitrogen isotopes $\left(\delta^{15} \mathrm{~N}\right)$ measured on bulk sediment and on diatoms [Reynolds et al., 2008; Bailey et al., 2011; Studer et al., 2012] (Fig. 3). Using Equations 2/3 and subarctic North Pacific Ocean values for $\delta^{30} \mathrm{Si}(\mathrm{OH})_{4}$ and $\varepsilon$ of $1.23 \%$ and 1.0 respectively [Reynolds et al., 2006], we calculate rates of $\mathrm{Si}(\mathrm{OH})_{4}$ utilization for ODP Site 882 (Fig. 3). Rather than remaining stable, rates of $\mathrm{Si}(\mathrm{OH})_{4}$ utilization at ODP Site 882 show a longterm shift to lower values after $2.73 \mathrm{Ma}$ (Fig. 3). This trend could be related to increases in dust/iron deposition [Bailey et al., 2011] and indicates a gradually more under-utilized pool of $\mathrm{Si}(\mathrm{OH})_{4}$ in the subarctic Pacific Ocean after 2.73 Ma. Consequently, subarctic North Pacific waters exported through the Kamchatka Strait into the Bering Sea would have become progressively more enriched in $\mathrm{Si}(\mathrm{OH})_{4}$ between $2.73 \mathrm{Ma}$ and $2.58 \mathrm{Ma}$, leading to the observed pattern of higher rates of $\mathrm{Si}(\mathrm{OH})_{4}$ supply to Site U1341 over the same interval (Fig. 3).

\subsection{Opal productivity increase from 2.58 Ma}

Both $\mathrm{Si}(\mathrm{OH})_{4}$ supply and opal MAR at Site U1341 increase abruptly from $2.58 \mathrm{Ma}$ onwards, indicating a major change in the regional water column structure. Prior to $3.1 \mathrm{Ma}$ the region around Bowers Ridge was characterized by relatively warm waters both at Site U1340 and U1341 [Chen et al., 2014; Zhang et al., 2014; Stroynowski et al., 2015] (Fig. 1). Thereafter, and in particular with the onset of major NHG, diatom and radiolarian assemblages indicate a gradual cooling that accelerated with the emergence of low-salinity surface waters related to the expansion of sea ice [Chen et al., 2014; Zhang et al., 2014; Stroynowski et al., 2015]. Values of $\delta^{18} \mathrm{O}_{\text {diatom }}$ at Site U1341 differ considerably from those reported at ODP Site 882 in terms of the magnitude and timing of isotope changes [Haug et al., 2005, Swann et al., 2006; Swann, 2010], reflecting differences in temperature, glacial meltwater and precipitation inputs at each site. At Site U1341 the onset of major NHG is associated with a shift in $\delta^{18} \mathrm{O}_{\text {diatom }}$ to more variable values including frequent increases to $41-42 \%$, indicative of the emergence of colder surface water conditions (Fig. 2). No clear link exists between $\delta^{18} \mathrm{O}_{\text {diatom }}$ and rates of $\mathrm{Si}(\mathrm{OH})_{4}$ supply/opal MAR at U1341 prior to $2.58 \mathrm{Ma}$. However, the increase in siliceous productivity after $2.58 \mathrm{Ma}$ coincides with the stabilization of $\delta^{18} \mathrm{O}_{\text {diatom }}$ at high values (c. 42\%o) (Fig. 2). This change, advocating the transition to persistent colder surface waters, is concordant with increases in the relative abundance of the diatoms Neodenticula koizumii and Actinocyclus curvatulus, interpreted as indicating a decrease in sea surface temperatures [Onodera et al., 2016]. 
Accepted for publication in Paleoceanography (http://dx.doi.org/10.1002/2016PA002978)

Phytoplankton dynamics in the Bering Sea are primarily regulated by a combination of winter winds, mixing the water column and supplying nutrients to the photic zone, and seasonal stratification, either linked to spring sea ice melt and/or seasonal increases in solar insolation [Katsuki and Takahashi, 2005]. We propose that the transition to persistent cold conditions at $2.58 \mathrm{Ma}$, as indicated by $\delta^{18} \mathrm{O}_{\text {diatom, }}$, is linked to enhanced wind-driven mixing at Site U1341 that significantly increased the advection of cold, $\mathrm{Si}(\mathrm{OH})_{4}$-rich, deep water exported from the subarctic North Pacific Ocean to the surface at Bowers Ridge. This explains the abrupt increase in $\mathrm{Si}(\mathrm{OH})_{4}$ supply at $2.58 \mathrm{Ma}$ and does not necessitate an abrupt increase in nutrient leakage through the Kamchatka Strait at 2.58 Ma. An increase in wind-driven mixing could be linked to either regional changes in the Aleutian storm track and/or global changes in storm/cyclone frequency and sea-surface temperature gradients [Fedorov et al., 2013; 2015]. In addition, a shift to a more productive environment would also be supported by the observed increases in regional sea ice from c. 2.65-2.60 Ma onwards [Onodera et al., 2016; Stroynowski et al., 2015]. Whilst Site U1341 lies south of the current sea ice, expansion of sea ice beyond the Bering shelf break has also been documented in late Quaternary glacial periods [Katsuki and Takahashi, 2005; Caissie et al., 2010].

In summary, the combination of increases in wind-driven mixing, sea ice-driven stratification and photic zone $\mathrm{Si}(\mathrm{OH})_{4}$ supply at $2.58 \mathrm{Ma}$ would have created oceanographic conditions similar to those found along the Bering Shelf today, in which phytoplankton blooms are aided by sea ice melt that creates a seasonally stratified system which entrains diatoms in the photic zone [Aguilar-Islas et al., 2007; Ladd and Stabeno, 2012; Brown and Arrigo, 2013]. This interpretation is supported by both diatom assemblages, indicating nutrient-depleted stratified surface waters in summer months following the main diatom bloom [Stroynowski et al., 2015], and slightly higher levels of $\mathrm{Si}(\mathrm{OH})_{4}$ utilization in 4 of the 6 samples analyzed post $2.58 \mathrm{Ma}$ (Fig. 2). The highly variable rates of $\mathrm{Si}(\mathrm{OH})_{4}$ utilization and $\mathrm{Si}(\mathrm{OH})_{4}$ supply from 2.58-2.52 Ma, however, advocates the need for further work on this interval and may reflect short-term changes in either sea-ice abundance, wind-driven advection and/or nutrient leakage to the Bering Sea (Fig. 2).

\section{Conclusions}

Diatom isotope records from Site U1341 in the south Bering Sea show that the onset of major NHG from c. 2.73 Ma coincided with a series of changes that culminated in an abrupt increase in siliceous productivity at 2.58 Ma. Between $2.73 \mathrm{Ma}$ and $2.58 \mathrm{Ma}$ rates of $\mathrm{Si}(\mathrm{OH})_{4}$ supply to the photic zone gradually increased, attributed to nutrient leakage from the subarctic northwest Pacific Ocean where a corresponding decline in $\mathrm{Si}(\mathrm{OH})_{4}$ utilization is apparent over the same period. At the same time $\delta^{18} \mathrm{O}_{\text {diatom }}$ indicates a variable, but progressive, shift to colder conditions. These changes end after $2.58 \mathrm{Ma}$ with an abrupt increase in $\mathrm{Si}(\mathrm{OH})_{4}$ supply to the photic zone, fueling the observed increase in opal concentrations. With $\delta^{18} \mathrm{O}_{\text {diatom }}$ suggesting a shift to persistently colder conditions from $2.58 \mathrm{Ma}$, increased $\mathrm{Si}(\mathrm{OH})_{4}$ supply from the deep to surface waters at Site U1341 could be linked to increased wind-driven mixing of the water column. In any case, increased $\mathrm{Si}(\mathrm{OH})_{4}$ availability in the photic zone, combined with microfossil evidence for increased sea ice and a seasonally stratified water column, would have created optimal conditions for high levels of siliceous productivity. Further research is now needed to assess the long-term impact of this nutrient leakage from the subarctic Northwest Pacific Ocean to the Bering Sea. Did this leakage culminate in the early Quaternary, or did nutrient leakage from the subarctic Pacific continue to play a key role in Bering Sea 
Accepted for publication in Paleoceanography (http://dx.doi.org/10.1002/2016PA002978)

biogeochemical cycling through the Quaternary - for example over glacial-interglacial cycles in line with documented shifts between intervals of higher (interglacial) and lower (glacial) productivity [Katsuki and Takahashi 2005; Iwasaki et al., 2016]?

\section{Acknowledgments and Data}

Supporting data $\left(\delta^{18} \mathrm{O}_{\text {diatom }}\right.$ and $\delta^{30} \mathrm{Si}_{\text {diatom }}$ data from Site U1341 between 2.93 Ma and 2.52 Ma) are included as a spreadsheet in the SI. This work was funded through Natural Environment Research Council (NERC) grant NE/I005889/1. Thanks are owed to Hilary Sloane [NIGL/BGS] for assistance with the sample analysis, Sev Kender [University of Nottingham] for commenting on an earlier version of the manuscript and to Christian März, an anonymous reviewer and the editorial team at Paleoceanography for their constructive comments.

\section{References}

Aguilar-Islas, A. M., M. P. Hurst, K. N. Buck, B. Sohst, G. J. Smith, M. C. Lohan, and K.W. Bruland (2007), Micro- and macronutrients in the southeastern Bering Sea: Insight into iron-replete and iron-depleted regimes, Prog Oceanogr., 73, 99-126.

Bailey, I., Q, Liu, G. E. A. Swann, Z. Jiang, Y. Sun, X. Zhao, and A. P. Roberts, A.P. (2011), Iron fertilisation and biogeochemical cycles in the sub-Arctic northwest Pacific during the late Pliocene intensification of northern hemisphere glaciation, Earth Planet Sc Lett., 307, 253-265.

Brown, Z. W., and K. R. Arrigo (2013), Sea ice impacts on spring bloom dynamics and net primary production in the Eastern Bering Sea, J Geophys Res., 118, 43-63.

Brown, Z. W., G. L van Dijken, and K. R. Arrigo (2011), A reassessment of primary production and environmental change in the Bering Sea, J Geophys Res., 116, C08014, doi:10.1029/2010JC006766.

Caissie, B. E., J. Brigham-Grette, K. T. Lawrence, T. D. Herbert, and M. S. Cook (2010), Last Glacial Maximum to Holocene sea surface conditions at Umnak Plateau, Bering Sea, as inferred from diatom, alkenone, and stable isotope records, Paleoceanography, 25, PA1206, doi:10.1029/2008PA001671.

Chapligin, B., M. Leng, E. Webb, A. Alexandre, J. Dodd, A. Ijiri, A. Lucke, A. Shemesh, A. Abelmann-Gersonde, U. Herzschuh, F. Longstaffe, H. Meyer, R. Moschen, Y. Okazaki, N. Rees, Z. Sharp, H. Sloane, C. Sonzogni, G. Swann, F. Sylvestre, J. Tyler, and R. Yam (2011), Inter-laboratory comparison of oxygen isotope compositions from biogenic silica, Geochim. Cosmochim. Ac., 75, 7242-7256.

Chen, M. -H., Q. Zhang, L. -L. Zhang, C. Alvarez Zarikian and R. -J. Wang (2014), Stratigraphic distribution of the radiolarian Spongodiscus biconcavus Haeckel at IODP Site U1340 in the Bering Sea and its paleoceanographic significance. Palaeoworld 23, 90-104.

Coachman, L. K., T. E. Whitledge, and J. J. Goering (1999), in T. R. Loughlin and K. Ohtani, eds., Dynamics of the Bering Sea: Fairbanks, University of Alaska Sea Grant Press, AKSG-99-03, 285-310.

Cokelet, E. D., M. L. Schall, and D. M. Dougherty, D.M (1996), ADCP- referenced geostrophic circulation in the Bering Sea, J Phys Oceanogr., 26, 1113-1128. 
Accepted for publication in Paleoceanography (http://dx.doi.org/10.1002/2016PA002978)

Cortese, G., R. Gersonde, C. -D. Hillenbrand, and G. Kuhn (2004), Opal sedimentation shifts in the World Ocean over the last 15 Myr, Earth Planet Sc Lett., 224, 509-527.

de La Rocha, C.L., M. A. Brzezinski, and M. J. DeNiro (1997), Fractionation of silicon isotopes by marine diatoms during biogenic silica formation, Geochim. Cosmochim. Ac. 61, 5051-5056.

de la Rocha, C. L. (2003), Silicon isotope fractionation by marine sponges and the reconstruction of the silicon isotope composition of ancient deep water, Geology, 31, 423-426.

de da Rocha, C. L. (2006), Opal-based isotopic proxies of paleoenvironmental conditions, Global Biogeochem Cy., 20, GB4S09, doi:10.1029/2005GB002664.

Etourneau, J., C. Ehlert, M. Frank, P. Martinez, and R. Schneider (2012), Contribution of changes in opal productivity and nutrient distribution in the coastal upwelling systems to Late Pliocene/Early Pleistocene climate cooling, Clim Past., 8, 1435-1445.

Expedition 323 Scientists (2011), Site U1341. In Takahashi, Ravelo, A.C., K., Alvarez Zarikian, C.A., and the Expedition 323 Scientists, Proc. IODP, 323: Tokyo (Integrated Ocean Drilling Program Management International, Inc.). doi:10.2204/iodp.proc.323.105.2011.

Fedorov, A. V., C. M. Brierley, K. T. Lawrence, Z. Liu, P. S. Dekens, and A. C. Ravelo (2013), Patterns and mechanisms of early Pliocene warmth, Nature, 496, 43-48.

Fedorov, A. V., N. J. Burls, K. T. Lawrence, and L. C. Peterson (2015), Tightly linked zonal and meridional sea surface temperature gradients over the past five million years, Nat Geosci, 8, 975-980.

Fripiat, F., A. -J. Cavagna, F. Dehairs, S. Speich, L. André, and D. Cardinal (2011), Silicon pool dynamics and biogenic silica export in the Southern Ocean inferred from Si-isotopes, Ocean Sci., 7, 533-547.

Haug, G. H., D. M. Sigman, R. Tiedemann, T. F. Pedersen, and M. Sarnthein (1999), Onset of permanent stratification in the subarctic Pacific Ocean, Nature, 401, 779-782.

Haug, G. H., A. Ganopolski, D. M. Sigman, A. Rosell-Mele, G. E. A. Swann, R. Tiedemann, S. Jaccard, J. Bollmann, M. A. Maslin, M. J. Leng, and G. Eglinton (2005), North Pacific seasonality and the glaciation of North America 2.7 million years ago, Nature, 433, 821825.

Hendry, K. R., and L. F. Robinson (2012), The relationship between silicon isotope fractionation in sponges and silicic acid concentration: Modern and core-top studies of biogenic opal, Geochim. Cosmochim. Ac., 81, 1-12.

Hendry, K. R., and M. A. Brzezinski (2014), Using silicon isotopes to understand the role of the Southern Ocean in modern and ancient biogeochemistry and climate, Quaternary Science Reviews, 89, 13-26.

Hidy, A. J., J. C. Gosse, D. G. Froese, J. D. Bond, and D. H. Rood (2013), A latest Pliocene age for the earliest and most extensive Cordilleran Ice Sheet in northwestern Canada, Quaternary Sci Rev., 61, 77-84. 
Accepted for publication in Paleoceanography (http://dx.doi.org/10.1002/2016PA002978)

Hoffmann, L. J., I. Peeken, and K Lochte (2007), Effects of iron on the elemental stoichiometry during EIFEX and in the diatoms Fragilariopsis kerguelensis and Chaetoceros dichaeta, Biogeosciences, 4, 569-579.

Horn, M. G., C. P. Beucher, R. S. Robinson, and M. A. Brzezinski (2011), Southern ocean nitrogen and silicon dynamics during the last deglaciation, Earth and Planet Sc Lett. 310, 334-339.

Hutchins, D. A., and K. W. Bruland (1998), Iron-limited diatom growth and Si:N uptake ratios in a coastal upwelling regime, Nature, 393, 561-564.

Ikenoue, T., Y. Okazaki, Z. Takahashi, and T. Sakamoto (2016), Bering Sea radiolarian biostratigraphy and paleoceanography at IODP Site U1341 during the last four million years, Deep-Sea Res Pt II., 125-126, 38-55.

Iwasaki, S., K. Takahashi, Y. Kanematsu, H. Asahi, J. Onodera, and A. C. Ravelo (2016), Paleoproductivity and paleoceanography of the last 4.3 Myrs at IODP Expedition 323 Site U1341 in the Bering Sea based on biogenic opal content, Deep-Sea Res Pt II., 125$126,145-154$.

Katsuki, K., and K. Takahashi (2005) Diatoms as paleoenvironmental proxies for seasonal productivity, sea-ice and surface circulation in the Bering Sea during the late Quaternary, Deep-Sea Res Pt II., 52, 2110-2130.

Kinney, J. C., and W. Maslowski (2012), On the oceanic communication between the Western Subarctic Gyre and the deep Bering Sea, Deep-Sea Res Pt I., 66, 11-25.

Ladd, C., and P. J. Stabeno (2012), Stratification on the Eastern Bering Sea shelf revisited, DeepSea Res Pt II., 65-70, 72-83.

Leng, M. J., and H. J. Sloane (2008), Combined oxygen and silicon isotope analysis of biogenic silica, J Quaternary Sci., 23, 313-319.

März, C., B. Schnetger, and H. -J. Brumsack (2013), Nutrient leakage from the North Pacific to the Bering Sea (IODP Site U1341) following the onset of Northern Hemispheric Glaciation?, Paleoceanography, 28, 68-78.

Maslin, M. A., G. H. Haug, M. Sarnthein, and R. Tiedemann (1996), The progressive intensification of northern hemisphere glaciation as seen from the North Pacific, Geol Rundsch., 85, 452-465.

Milligan, A. J., D. E. Varela, M. A. Brzezinski, and F. O. M. M. Morel (2004), Dynamics of silicon metabolism and silicon isotopic discrimination in a marine diatom as a function of $p \mathrm{CO}_{2}$, Limnol. Oceanogr. 49, 322-329.

Mudelsee, M., and M. E. Raymo (2005), Slow dynamics of the Northern Hemisphere glaciation, Paleoceanography, 20, PA4022, doi:10.1029/2005PA001153.

Onodera, J., K. Takahashi, and R. Nagatomo (2016), Diatoms, silicoflagellates, and ebridians at Site U1341 on the western slope of Bowers Ridge, IODP Expedition 323, Deep-Sea Res Pt II., 125-126, 8-17.

Ravelo, A. C., D. H. Andreasen, M. Lyle, A. O. Lyle, and M. W. Wara (2004), Regional climate shifts caused by gradual global cooling in the Pliocene epoch, Nature, 429, 263-267. 
Accepted for publication in Paleoceanography (http://dx.doi.org/10.1002/2016PA002978)

Raymo, M. E. (1994), The Himalayas, organic carbon burial, and climate in the Miocene, Paleoceanography, 9, 399-404.

Reed, R. K., G. V. Khen, P. J. Stabeno, and A. V. Verkhunov (1993), Water properties and flow over the deep Bering Sea basin, summer 1991, Deep-Sea Res Pt I., 40, 2325-2334.

Reynolds, B. C., M. Frank, and A. N. Halliday (2006), Silicon isotope fractionation during nutrient utilization in the North Pacific, Earth Planet Sc Lett., 244, 431-443.

Reynolds, B. C., J. Aggarwal, L. André, D. Baxter, C. Beucher, M. A. Brzezinski, E. Engström, R. B. Georg, M. Land, M. J. Leng, S. Opfergelt, I. Rodushkin, H. J. Sloane, S. H. J. M. van den Boorn, P. Z. Vroom, and D. Cardinal (2007), An inter-laboratory comparison of Si isotope reference materials, J Anal Atom Spectrom., 22, 561-568.

Reynolds, B. C., M Frank, and A. N. Halliday (2008), Evidence for a major change in silicon cycling in the subarctic North Pacific at $2.73 \mathrm{Ma}$, Paleoceanography 23, PA4219, doi:10.1029/2007PA001563.

Rho, T., and T. E. Whitledge (2007), Characteristics of seasonal and spatial variations of primary production over the southeastern Bering Sea shelf, Cont Shelf Res., 27, 2556-2569.

Sambrotto, R. N., J. J. Goering, and C. P. McRoy (1984), Large Yearly Production of Phytoplankton in the Western Bering Strait, Science, 225, 1147-1150.

Shimada, C., T. Sato, M. Yamasaki, S. Hasegawa, and Y. Tanaka (2009) Drastic change in the late Pliocene subarctic Pacific diatom community associated with the onset of the Northern Hemisphere Glaciation, Palaeogeogr Palaeocl., 279, 207-215.

Sigler, M. F., P. J. Stabeno, L. B. Eisner, J. M. Napp, and F. J. Mueter (2014), Spring and fall phytoplankton blooms in a productive subarctic ecosystem, the eastern Bering Sea, during 1995-2011, Deep-Sea Res Pt II., 109, 71-83.

Sigman, D. M., S. L. Jaccard, and G. H. Haug (2004) Polar ocean stratification in a cold climate, Nature, 428, 59-63.

Snelling, A. M., G. E. A. Swann, J. Pike, and M. J. Leng (2014) Pliocene diatom and sponge spicule oxygen isotope ratios from the Bering Sea: isotopic offsets and future directions, Clim Past., 10, 1837-1842

Stabeno, P. .J., J. D. Schumacher, and K. Ohtani (1999), Physical oceanography of the Bering Sea. In: The Bering Sea: a Summary of Physical, Chemical and Biological Characteristics and a Synopsis of Research. T. R. Loughlin, and K. Ohtani (ed). North Pacific Marine Science Organization, PICES, Alaska Sea Grant Press, pp. 1-28.

Stroynowski, Z., and A. C. Ravelo, and D. Andreasen (2015), A Pliocene to recent history of the Bering Sea at Site U1340A, IODP Expedition 323, Paleoceanography, 30, 1641-1656.

Studer, A. S., A. Martínez-Garcia, S. L. Jaccard, F. E. Girault, D. M. Sigman, and G. H. Haug (2012), Enhanced stratification and seasonality in the Subarctic Pacific upon Northern Hemisphere Glaciation-New evidence from diatom-bound nitrogen isotopes, alkenones and archaeal tetraethers, Earth Planet Sc Lett., 351-352, 84-94. 
Accepted for publication in Paleoceanography (http://dx.doi.org/10.1002/2016PA002978)

Swann, G. E. A. (2010), Salinity changes in the North West Pacific Ocean during the late Pliocene/early Quaternary from 2.73 Ma to 2.53 Ma, Earth Planet Sc Lett., 297, 332-338, 2010.

Swann, G. E. A., and M. J. Leng (2009) A review of diatom $\delta^{18} \mathrm{O}$ in palaeoceanography, Quaternary Sci Rev., 28, 384-398.

Swann, G. E. A., M. A. Maslin, M. J. Leng, H. J. Sloane, and G. H. Haug (2006), Diatom $\delta^{18}$ O evidence for the development of the modern halocline system in the subarctic northwest Pacific at the onset of major Northern Hemisphere glaciation, Paleoceanography, 21, PA1009, doi:10.1029/2005PA001147.

Swann, G. E. A., M. J. Leng, H. J. Sloane, M. A. Maslin, and J. Onodera (2007), Diatom oxygen isotopes: evidence of a species effect in the sediment record. Geochem Geophy Geosy., 8, Q06012, doi:10.1029/2006GC001535.

Swann, G. E. A., M. J. Leng, H. J. Sloane, and M. A. Maslin, M. A (2008), Isotope offsets in marine diatom $\delta^{18} \mathrm{O}$ over the last $200 \mathrm{ka}$, J Quaternary Sci., 23, 389-400.

Swann, G. E. A., J. Pike, A. M. Snelling, M. J. Leng, and M. C. Williams (2013), Seasonally resolved diatom $\delta^{18} \mathrm{O}$ records from the west Antarctic Peninsula over the last deglaciation, Earth Planet Sc Lett., 364, 12-23.

Takahashi, K. (2005), The Bering Sea and paleoceanography, Deep-Sea Res Pt II., 52, 20802091.

Takahashi, K., A. C. Ravelo, and C. A. Alvarez Zarikian, Expedition 323 Scientists (2011) In: Proceedings of the Integrated Ocean Drilling Program 323: Integrated Ocean Drilling Program Management International, Inc., Tokyo.

Takeda, S. (1998), Influence of iron availability on nutrient consumption ratio of diatoms in oceanic waters, Nature, 393, 774-777.

Tiedemann, R., and G. H. Haug (1995), Astronomical calibration of cycle stratigraphy for site 882 in the northwest Pacific, Proc. Ocean Drill. Program Sci. Results, 145, 283 - 292.

Varela, D. E., C. J. Pride, and M. A. Brzezinski (2004), Biological fractionation of silicon isotopes in Southern Ocean surface waters, Global Biogeochem. Cy., 18, doi:10.1029/2003GB002140.

Wehrmann, L. M., S. Arndt, C. März, T. G. Ferdelman, and B. Brunner (2013), The evolution of early diagenetic signals in Bering Sea subseafloor sediments in response to varying organic carbon deposition over the last 4.3 Ma, Geochim. Cosmochim. Ac., 109, 175196.

Wille, M., J. Sutton, M. J. Ellwood, M. Sambridge, W. Maher, S. Eggins, and M. Kelly (2010), Silicon isotopic fractionation in marine sponges: A new model for understanding silicon isotopic variations in sponges, Earth Planet Sc Lett., 292, 281-289.

Zhang, Q., M. Chen, L. Zhang, W. Hu, and R. Xiang (2014), Variations in the radiolarian assemblages in the Bering Sea since Pliocene and their implications for paleoceanography, Palaeogeogr Palaeocl., 410, 337-350. 
Accepted for publication in Paleoceanography (http://dx.doi.org/10.1002/2016PA002978)

\section{Figures}

Figure 1: a) Map showing location of Hole U1341B at IODP Site 1341 (54 $1.9984^{\prime} \mathrm{N}$, $\left.179^{\circ} 0.5171^{\prime} \mathrm{E}\right)$ and Hole U1340A at IODP Site $1340\left(53^{\circ} 24.0008^{\prime} \mathrm{N}, 179^{\circ} 31.2973^{\prime} \mathrm{W}\right)$ on Bowers Ridge in the Bering Sea and ODP Site 882 in the subarctic North West Pacific Ocean $\left(50^{\circ} 21.797^{\prime} \mathrm{N}, 167^{\circ} 35.999^{\prime} \mathrm{E}\right)$ together with surface (red lines) and subsurface (dashed green lines) water circulation in the Bering Sea [adapted from Stabeno et al., 1999; Takahashi et al., 2011]. b) Cross sections of the passes and volume transport (Sv) in the Aleutian Island [adapted from Stabeno et al., 1999; Takahashi, 2005; Takahashi et al., 2011].

Figure 2: $\delta^{18} \mathrm{O}_{\text {diatom }}$ and $\delta^{30} \mathrm{Si}_{\text {diatom }}$ at Site U1341 together with calculated estimates of $\mathrm{Si}(\mathrm{OH})_{4}$ utilization, $\mathrm{Si}(\mathrm{OH})_{4}$ supply and opal MAR [Iwasaki et al., 2016]. Rates of $\mathrm{Si}(\mathrm{OH})_{4}$ supply are relative to a value of $100 \%$ in the uppermost sample at $2.52 \mathrm{Ma}$ and, for clarity, the $\mathrm{y}$-axis on the plot is log transformed. Vertical dashed lines indicate onset of major NHG (2.73) and the opal MAR increase at Site U1341 at 2.58 Ma. Sedimentation rates (gray line) and age control points (coloured triangles) are from Table 1 in Iwasaki et al. [2016]. Blue and red dashed lines for the control points at 2.64 Ma and 2.65 Ma are the age errors also reported within Table 1 in Iwasaki et al. [2016].

Figure 3: Comparison of $\delta^{30} \mathrm{Si}_{\text {diatom }}$ and $\mathrm{Si}(\mathrm{OH})_{4}$ utilization at ODP Site 882 (Fig. 1) in the subarctic Northwest Pacific Ocean with $\mathrm{Si}(\mathrm{OH})_{4}$ supply and opal MAR [Iwasaki et al., 2016] at Site U1341in the Bering Sea. For clarity the y-axis on the $\mathrm{Si}(\mathrm{OH})_{4}$ supply data plot from Site U1341 is log transformed. Vertical dashed lines indicate onset of major NHG (2.73) and the opal MAR increase at Site U1341 at 2.58 Ma. The age model for ODP Site 882 is based on the linear interpolation of sedimentation rates between tie-points derived from the astronomical calibrated of high resolution GRAPE density and magnetic susceptibility measurements [Tiedemann and Haug, 1995]. 
A) Accepted for pưblication in Paleoceanography (http://dx.doi.org/10.1002/2016PA002978)
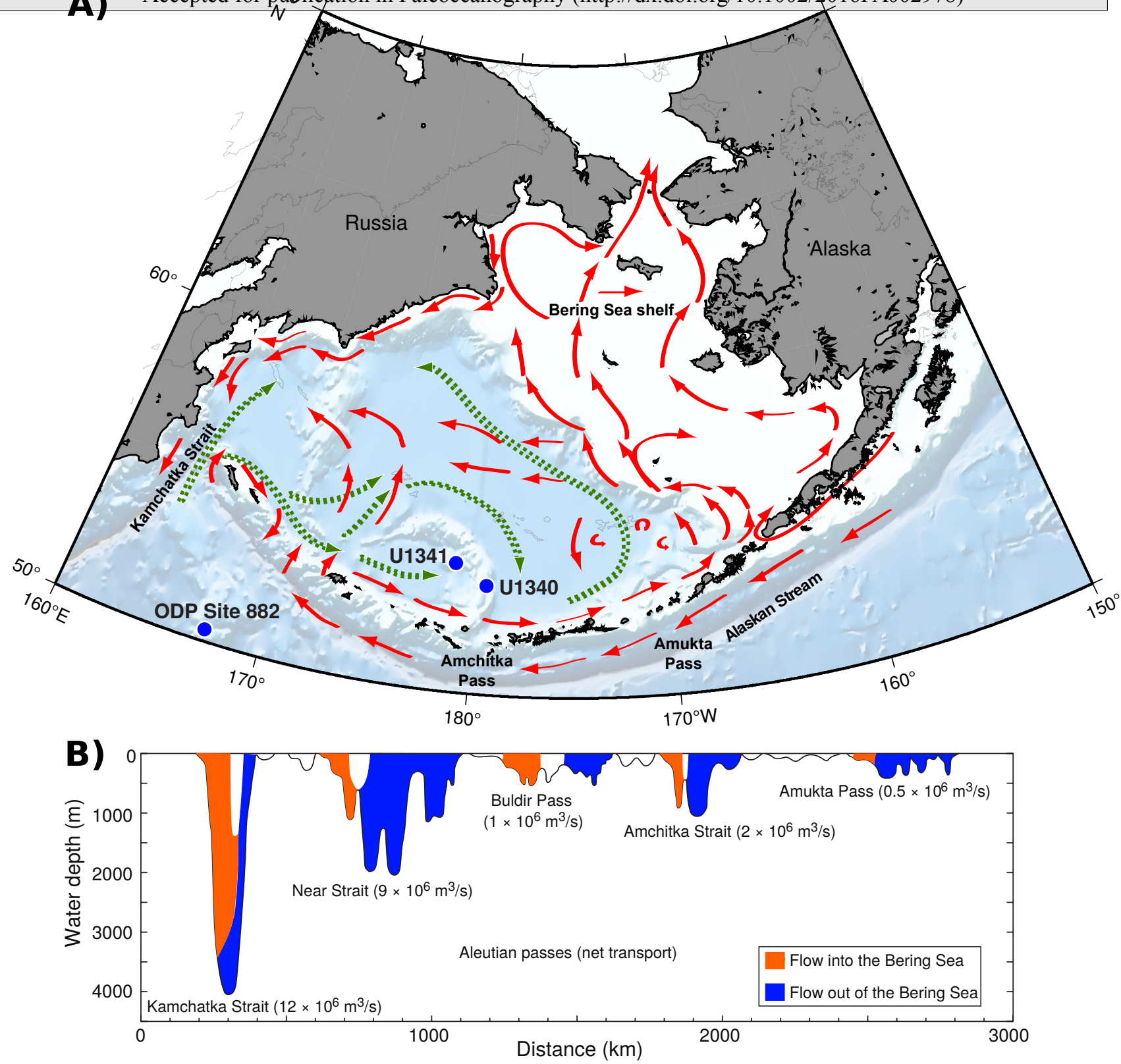

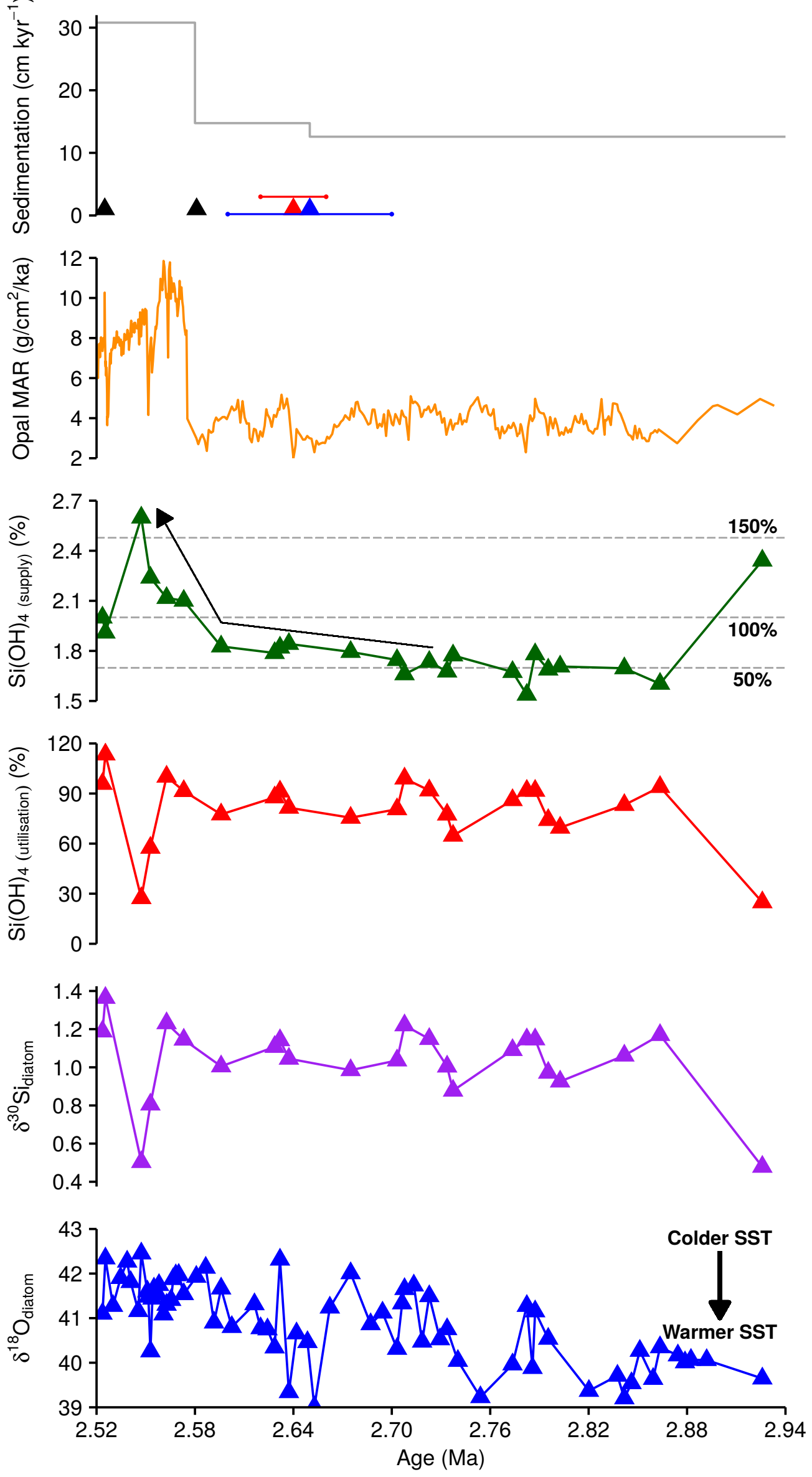

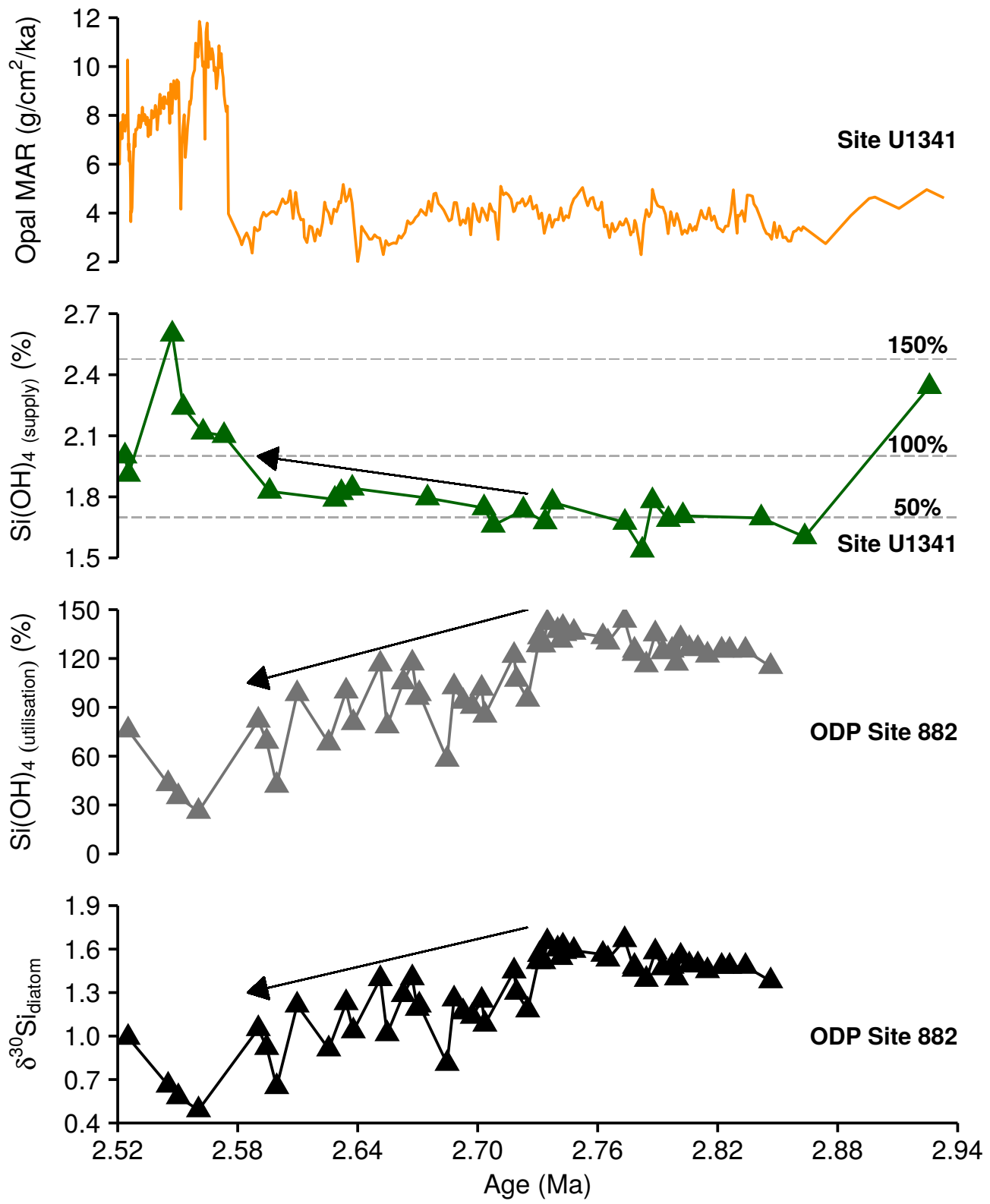